\title{
Exploration on the Existing Status and Development Path of Old Trades of Wuhan City
}

\author{
Jing Liang \\ Hubei Institute of Fine Arts \\ Wuhan, Hubei, 430205
}

\begin{abstract}
As the significant carrier of witnessing China's social changes, old trades play a very important role in Chinese traditional culture. Wuhan being an important economic town in east China, various old trades have played active roles in its development. However, in the urbanization process of Wuhan, many old trades have completely faded out of our life. How to well protect the old trades and play the positive role of craftsmanship spirit in the social development on the bas is is a significant problem that needs to be urgently solved in the development of each city at present stage. Based on this, this paper analyzed and explored the existing situation and development path of old trades of Wuhan.
\end{abstract}

Keywords-old trades; the spirit of originality; cultural inheritance; innovative development; protection

\section{INTRODUCTION}

Wuhan, as the biggest city in east China, is a very important commercial port in its historical development, whenever it is in the feudal society or the Republican period. And it is the reason why this city can play a very positive role in all the trades. They are oriented with traditional craftsmanship labor and traditional service industry, which has intense characteristics of Jingchu. It can well show the wisdom of predecessors and craftsmanship spirit of staff in this industry. However, with the continuous improvement of urban modernization, these trades have gradually faded out of people's view. But their craftsmanship and unique charm still have a very profound influence on the development of modern society. Only by well protecting, inheriting and developing the old trades can Wuhan realize its long-term development in a real sense.

\section{OVERVIEW OF WUHAN OLD INDUSTRY}

\section{A. The meaning of the old trades of Wuhan}

At the present stage, there are many definitions of old trades. One of them is: The old trades refer to the industry which is hard to see in the process of social development at this stage. Another way of this is that old trades are a general term for all walks of life that are disappearing in society. The socalled Wuhan old trades, I believe, refers to a general term in all walks of life that have disappeared or are disappearing in the process of urban development of Wuhan. For the old trades of Wuhan, in the process of its urban development, due to its special geographical location, the city of Wuhan has a variety of trades in its development process. Most of these professions

Funding project: Guiding project of science and technology research program of Hubei Ministry of Education in 2018, Cultural restoration - old trades of Wuhan, project number: B2018131. are mainly traditional handicrafts and traditional service industries, with a very strong Jingchu style. For example, shoemaker, carpenter, copper painter, tailor, locksmith, rattan maker, etc. Although the present stage of social development and urban modernization drive a lot of old trades of art and service has been fading out of people, it is undeniable that the old Wuhan is an indispensable part of the Jingchu culture, and the ingenuity is still playing a very active role in the development and progress of Wuhan.

\section{B. Analysis of the development of the old trades of Wuhan}

Throughout the development of the whole city of Wuhan, it has always been a heavy commercial town in East China, whether in feudal society or in the period of the Republic of China. It is precisely because of this, the skilled craftsmen in the Wuhan region have also created a variety of old Jingchu characteristics, such as kneading mud man, kneading face, sugar painting and so on. This kind of old trades is closely related to people's life, and plays a very positive role in displaying the unique world outlook and creativity of the Jingchu people, which has a profound influence on the development of Wuhan city. Moreover, many excellent old trades have not only high social value, but also high cultural value. However, with the improvement of the level of urban modernization and the rapid development of society, more and more modern scientific and technological products come to more influence on people's daily life, and the influence of various old trades of Wuhan on modern life is becoming smaller and smaller. As a result, a lot of traditional Wuhan professions with the characteristics of Jingchu, gradually fade out of people's vision, and some even face a very serious crisis of loss or extinction.

\section{AN ANALYSIS OF REASONS FOR THE GRADUAL DISAPPEARANCE OF THE OLD TRADES}

\section{A. Lack of awareness of protection and development in the old profession}

History tells us that during the process of social development, traditional things will eventually be replaced by new ones, and something outdated will inevitably die out, which is a very normal situation during social and history development. But for old trades, because they have a very positive impact on urban construction and social development in the process of inheritance and development, they could still represent the "craftsman spirit" of people in Jingchu area; also they have been playing an important role in the development of 
Wuhan city. There are many factors causing the fade or even disappearance of some Wuhan's old trades among which a very crucial point is the lack of corresponding protection and development consciousness of the old industry. For Wuhan Laoxing, it is not merely an important part of Jingchu traditional culture, but also a fundamental part in Chinese culture. It should be protected by government, but at present, Wuhan's non-posthumous protection list does not involve the corresponding characteristics of old trades What's more, the level of understanding and cognition of the relevant cultural management departments for some old professions is not so high. Many phenomena directly show that Wuhan hasn't attached much importance to the protection and development of old trades in the process of urban development. Under such a circumstance, it is difficult to truly pass on the "artisan spirit" of Jingchu area.

\section{B. Lack of corresponding talents guarantee mechanism in the process of inheriting old trades}

For the inheritance and development of old trades, people inheritance should be focused. Although at this stage Wuhan had included the protection and development of many old trades in the actual work of cultural inheritance, due to many factors, many young people do not want to know or inherit the skills of these old professions. As an important carrier of craftsman spirit, old trade still plays a very active role in showing the wisdom of Jingchu people and guiding the urban construction. Many factors contribute to the reluctance of many young people to inherit and develop skills and craftsmanship, for example, lower income and social status of craftsman, social impetuosity and lack of talent security. More and more young people are unwilling to pass on such skills at all. Therefore, only by doing a good job in talent guarantee mechanism, can we truly realize the inheritance and development of Wuhan's old skills and craftsmanship.

\section{No established associations or trade organizations for protecting their inheritance and development}

Most traditional businesses are mainly individual and scattered in streets and alleyways. There is no specific place, let alone a unified organization and protection for them by a fixed association or trade organization. In addition, the influence of modern science and technology civilization will make the development of old trades in the dispersive state more difficult in modern cities for a long period. As a result, it is hard to inherit and develop the artisan spirit and craftsman style of Jingchu area, whether it is the old trade with "Jingchu characteristics" or the "craftsman spirit” in Jingchu area.

\section{THE POSITIVE SIGNIFICANCE OF THE CULTURAL}

MANAGEMENT FUNCTION OF THE GOVERNMENT ON THE PROTECTION AND DEVELOPMENT OF OLD TRADES OF WUHAN.

For the old trades of Wuhan at the present stage, it is not only the inheritance and development of traditional craftsmanship but the inheritance and development of the "originality" in old trades in the process of its heritage and development. Since ancient times, its people have created a miracle after another in line with the craftmanship spirit, while the old trades, as the important carrier of "originality" and "craftsmanship spirit", belong to the category of cultural management in the process of social development at present stage. The government, as an important responsibility department in China's cultural management, has a very positive significance in the protection and development of old trades of Wuhan. For the government's cultural management function, it mainly includes three aspects: public cultural service function, cultural market management cultivation function and cultural industry development function. Therefore, the government plays a significant role in managing the heritage and development of old trades through the innovation of cultural management function. In this process, the rule of "people oriented" is followed in the process, and only by this way can the traditional skills and "craftsmanship spirit" be truly inherited and developed.

\section{ANALYSIS ON THE PROTECTION AND DEVELOPMENT OF} OLD TRADES OF WUHAN

\section{A. The government should give full play to its positive role in cultural management}

For the old trades of Wuhan, in order to realize its inheritance and development, one of the most important measures is that the government should give full play to the positive role of its own cultural management. First, the relevant government staff should fully understand the inheritance and development of the old Wuhan, and pay enough attention to its inheritance and protection. In this process, the government should appoint relevant staff to make statistics on the disappearing, disappearing and existing old trades. The corresponding protection measures are formulated according to the actual situation of urban development. Secondly, the government should innovate on its own cultural management function, and the relevant managers should establish the inheritance and protection consciousness of the old trades, and draw lessons from the advanced experience of other areas of our country. Combined with its own development practice, such as the protection experience of the old industry in Suzhou, Jiangsu, the protection of the old industry is realized in the true sense. In the end, the government should give full play to the role of the body in the organization and organize the whole society to participate in the actual protection and development of the old trades, encouraging people to find the old characteristics around the street, such as the bronze craftsmen through the streets, the shaving craftsmen in the corner and the tailor, and so on. The combination of the government and the folk forces has a very positive significance for the inheritance and development of Wuhan old trades with Jingchu characteristics.

\section{B. Increase the publicity of the craftsmanship of old trades}

For the old trades of Wuhan in the current stage, its role on people tends to show the "craftsmanship spirit" of craftsmen in the old trades. Therefore, in the process of inheritance and development of old trades of Wuhan, it is particularly important to promote the "craftsmanship spirit" of the old trades. In the development process of old industry of Wuhan, the author thinks that the propaganda work of "craftsmanship spirit" should be done from the following points. First, the 
government should give full play to their own cultural management function and promote the spirit of "originality" by organizing some activities, such as the related performance of "specials of old trades and originality". Secondly, the government should protect some endangered old trades with certain characteristics and endow the attributes of intangible cultural heritage to strengthen the propaganda degree of old trades on the basis. Only in this way can people truly recognize and understand it and realize the propaganda of "craftsmanship spirit" on this basis. Finally, the government should mobilize universities and social groups to study some old trades to provide strong theoretical guidance for the protection and development of old trades.

\section{Establish the corresponding organization or association to realize the protection and inheritance of the old trades}

All the trades are easily to be impacted by the social development in its real development process, especially the traditional old trades. But because of the particularity of the old trades, it is not organized and protected by the corresponding organization or association in its development process, which will lead to the more difficult development in the modern city of old trades in a dispersed state for a long-term. Thus, to achieve the inheritance and development of the old trades in Wuhan and carry forward the spirit of "originality" in the process of inheritance and development. Besides of the attention, the government should positively establish the corresponding trade protection organization and association to implement the protection and inheritance of old trades. Only by this way can we truly achieve the inheritance and development of the old trades in Wuhan.

\section{Strengthen the training of inheriting talents in the old industry}

As the main body of social development, people play a very important role in the inheritance and development of the old trades. But for old industry inheritance at present stage, a lot of young people don't want to pass the old trades skills and spirit due to the effect of many factors, which will easily lead to the disconnect of inheritance. Therefore, it is particularly important to do a good job of cultivating talents for the old trades. First of all, the government should establish a corresponding guarantee system for talents in the old trades, providing a strong guarantee for contemporary inheritors from the perspective of system. Secondly, it encourages modern young people to recognize and inherit such traditional skills and "craftsmanship spirit". Only by this way can the protection and development of Wuhan old trades be realized.

\section{CONCLUSION}

To sum up, although the old trades of Wuhan is gradually fading out of people's life at present, the craftsmanship spirit of old trades remains an indispensable part of Jingchu culture. Based on this kind of situation, both the government and old trades practitioners should connect the actual needs of urban development at the present stage, according to the facing difficulties in the process of the current development and adopt corresponding countermeasures to protect old industry and to realize the development of old trades on this basis. Although the skills in the old trades gradually fade out of people's eyes, its craftsmanship spirit still plays a very positive role in the process of urban development.

\section{REFERENCES}

[1] Fan Xiaomeng and Jiang Zili. Study on the inheritance and innovation of "old trades" in the course of urbanization in Yimeng mountain area[J]. Viewing and Hearing,2018(03):209-210.

[2] Zhang Hongyang. The social function and development trend of the old trades protection association -- taking Taizhou old trades association as an example[J]. Tangdu Journal,2017,33(06):120-124.

[3] Zhou Yuanting. "Old trades” in the watching[N]. Minnan Daily,201707-09(002).

[4] Lin Pingshan. Gradually disappearing old trades[J]. Employment and Security,2016(10):8-13.

[5] Wang Jia. Craftsman spirit in the old trades[N]. Ningbo Daily,2016-0411(011).

[6] Fang Penghui. An analysis on the existing situation and development path of old trades of Wuhan -- from the perspective of government cultural management function innovation[J]. Enterprise Leader,2016(01):69+68.

[7] $\mathrm{Ai}$ Ke. The new pace of old trades[J]. Employment and Security,2015(05):51-52.

[8] Zhang Hongyang. The existing situation and development path of the Old trades -- based on the investigation and analysis of Suzhou area[J]. Theoretical Guide, 2012(02):103-105. 